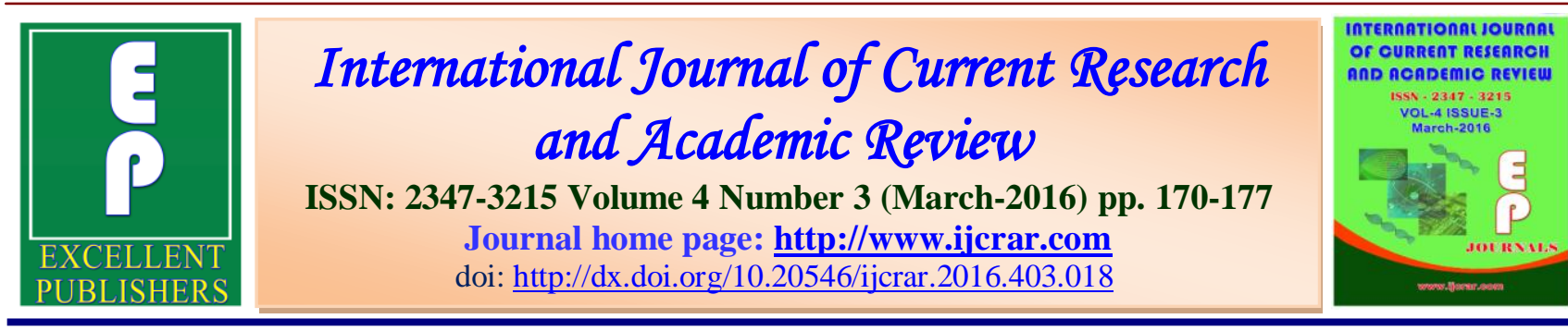

\title{
Protein Creatinine Ratio (PCR) from Random Urine Samples in Patients with Chronic Kidney Disease
}

\section{P.T. Komala*}

Department of Biochemistry, Meenakshi Medical College and Research Institute, Kanchipuram-631552, Tamil Nadu, India

*Corresponding author

\begin{tabular}{|c|c|}
\hline KEYWORDS & A B S T R A C T \\
\hline $\begin{array}{l}\text { Creatinine, } \\
\text { Proteinuria, } \\
\text { Chronic Kidney } \\
\text { disease }\end{array}$ & $\begin{array}{l}\text { The aims of this study was to assess the ability of Protein to Creatinine ratio } \\
\text { from random urine samples to rule in or rule out proteinuria in patients with } \\
\text { Chronic Kidney Disease. Chronic renal failure is a clinical syndrome } \\
\text { resulting in the progressive loss of renal function. The symptoms of chronic } \\
\text { renal failure result not only from simple excretory failure but also from the } \\
\text { onset of regulating failure, the kidney's failure to regulate certain substances, } \\
\text { such as sodium \& water. Chronic kidney disease patients were selected on the } \\
\text { basis of serum creatinine levels. In this study, we demonstrated that urinary } \\
\text { creatinine very helpful for chronic renal failure. Collection of } 24 \mathrm{hr} \text { urine } \\
\text { samples is cumbersome and prone to errors, hence analyte measurement in } \\
\text { random urine is often proposed with correction for variation in urine flow rate } \\
\text { by expressing results as a ratio to creatinine concentration. The tests are to be } \\
\text { used for monitoring the level of proteinuria in established renal disease, they } \\
\text { can then be used as surrogates for } 24 \mathrm{hr} \text { measurements }\end{array}$ \\
\hline
\end{tabular}

\section{Introduction}

Chronic renal failure is a clinical syndrome resulting in the progressive loss of renal function. The symptoms of chronic renal failure result not only from simple excretory failure but also from the onset of regulating failure, the kidney's failure to regulate certain substances, such as sodium \& water. ${ }^{1}$

According to the National Kidney Foundation-Kidney Dialysis Outcomes Quality Initiative (NKF-KDOQI) guidelines, chronic kidney disease is classified into 5stages. $^{2}$ The NKF-KDOQI guidelines stratify chronic kidney disease from stage 1 at the mild end of the spectrum to stage 5 which is severe. ${ }^{3}$ Stage $1 \& 2$ chronic kidney disease are usually not associated with any symptoms arising from the decrement in GFR. If the decline in GFR progresses to stages $3 \& 4$, clinical and laboratory complications of chronic kidney disease 
becomes more prominent. Virtually all organ systems are affected, but the most evident complications include anemia \& associated easy fatigability. If the patient progresses to stage 5 chronic kidney disease, toxins accumulate such that patients usually experience a marked disturbance in their activities of daily living, wellbeing, nutritional status, and water \& electrolyte homeostasis, culminating in the uremic syndrome. As discussed above, this state will end in death unless renal replacement therapy is instituted.

The dispiriting term end stage renal disease represents stage 5 of Chronic Kidney Disease where the accumulation of toxins, fluid and electrolytes results in the uremic syndrome. $^{2}$ Early identification is essential so that adverse outcomes of Chronic Kidney Disease can be prevented or treated. ${ }^{3}$ The identification and quantification of Proteinuria is important in the initial diagnosis and subsequent follow-up and monitoring of renal disease. Proteinuria is also recognised as an independent risk factor for cardiovascular disease and as a predictor end organ damage. Urine protein or albumin measurements now form a central part of the classification and guidelines for Chronic Kidney Disease.

There is no 'gold standard' for identifying proteinuria and although it has been generally accepted that the best measure of protein loss is that based on a $24 \mathrm{~h}$ urine collection, the variability of results obtained by this method make this view questionable. Quoted reference ranges for $24 \mathrm{~h}$ protein loss vary, but most would regard a protein loss of more than $150 \mathrm{mg} / 24 \mathrm{~h}$ as abnormal with significant proteinuria being greater than $300 \mathrm{mg} / 24 \mathrm{~h}$.

24hours urine collections, however, can be cumbersome to perform and prone to errors in collection. For this reason, the use of protein to creatinine ratios in random urine samples has been proposed. One systematic review of studies using random urine Protein: Creatinine Ratio concluded that they provided evidence to rule out significant proteinuria as defined by a 24 hours measurement. ${ }^{4}$

The aims of this study was to assess the ability of protein to creatinine ratio from random urine samples to rule in or rule out proteinuria in patients with Chronic Kidney Disease admitted in the Medicine department, Meenakshi Medical College and Research institute, Kanchipuram. By collecting additional urine at different points during the day the most appropriate random urine sample, if any could be determined.

\section{Materials and Methods}

\section{Subjects}

Chronic kidney disease patients were selected on the basis of serum creatinine levels. Serum creatinine $>2.5 \mathrm{mg} / \mathrm{dl}$ values were considered to be having chronic kidney disease. Both male and females patients with age ranging from 20-70yrs are taken in this study.

\section{Study Design}

The conducted study was a Correlation study.

\section{Target Population}

Target population was patients admitted in the Medicine Department of Meenakshi Medical College and Research institute, Kanchipuram, India.

\section{Sample Size}

60 samples were tested. Among that 36 cases were males and 24 cases were females. 


\section{Exclusion Criteria}

Patients with cardiac disease, pregnant women and those who required urgent dialysis are excluded from this study.

\section{Inclusion Criteria}

Patients with all stages of chronic kidney disease of any cause admitted in Meenakshi Medical College and Research institute, Kanchipuram, India are included in this study.

\section{Methodology and Data Collection}

\section{Collection of Serum Samples}

Serum samples were collected from the patients admitted in Medicine Department of Meenakshi Medical College and Research institute, Kanchipuram, India.

$5 \mathrm{ml}$ of venous blood will be collected from the patients.

All assays were performed within $48 \mathrm{hrs}$ of separation of serum. The collected samples were stored air tight at $2^{\circ} \mathrm{C}-8^{\circ} \mathrm{C}$ in the refrigerator.

\section{Collection of Urine Samples}

After discarding the first sample of the day 24hours urine sample of each patients is to be collected, in four separate containers 1) Second void, 2) Third void, 3) Remaining urine passed in that day \& 4) Early morning urine passed the following day.

Urine is to be collected into containers without preservative and stored at $4^{\circ} \mathrm{C}$ prior to analysis, which is usually within $24-28$ hours of receipt.

\section{Biochemical Analysis}

Serum creatinine, urinary creatinine was done manually by Jaffe's method using calorimeter, and urinary protein measurement was done using a kit method which is basically calorimetric method.

The present study comprises of 60 clinically diagnosed cases of chronic kidney disease. The age group ranges from 20-70 years, out of these, 36 patients were males and 24 patients were females. Statistical analysis on the data were performed using "Excel".

The main contributory causes for $\mathrm{CKD}$ in the 60 patients were diabetic nephropathy, \& hypertensive damage. Causes in 17 patients were not certain or under investigation. There were 19 patients with diabetes mellitus and 24 patients with hypertension. Out of this 12 patients with DM and 15 patients with HTN were males, and 7pateints with DM and 9 patients with HTN were females (Table.1).

$57 \%$ were men and the median age for all patients was $51.5 \pm 14.2175$. For all patients, median $24 \mathrm{hr}$ urinary protein loss was 2089.5 $\pm 580.192 \mathrm{mg} / 24 \mathrm{hr}$ and median urine volumes was $1.35 \pm 0.43333 \mathrm{~L} / 24 \mathrm{hr}$ (Table.2).

\section{Protein: Creatinine Ratio Versus 24 h Urine Proteins}

The present study shows a very good correlation between $24 \mathrm{hr}$ urine protein loss and protein to creatinine ratio (PCR) in second void, third voids and early morning urines, and these correlations were very similar for each of the three urine aliquots. PCR to be a good predictor of both abnormal urine protein loss and clinically significant urine protein loss.

\section{Correlation between PCR in Second Void Urine and 24hr Urinary Protein Loss}

There is a good correlation between $24 \mathrm{hr}$ urinary protein loss and PCR in second void 
urine. The correlation coefficient between them is 0.50479 . The graphical representation of this is shown in diagram. 1

\section{Correlation between PCR in Third Void Urine and 24hr Urinary Protein Loss}

There is a good correlation between $24 \mathrm{hr}$ urinary protein loss and PCR in third void urine. The correlation coefficient between them is 0.5064 . The graphical representation of this is shown in diagram. 2

\section{Correlation between PCR in First Void Urine and 24hr Urinary Protein Loss}

There is a good correlation between $24 \mathrm{hr}$ urinary protein loss and PCR in first void urine. The correlation coefficient between them is 0.69184. The graphical representation of this is shown in diagram.3.

\section{Craetinine Clearence}

There is a negative correlation between $24 \mathrm{hr}$ urinary protein loss and creatinine clearance, it means that if the creatinine clearance decreases the protein loss increases. That is, the creatinine clearance and $24 \mathrm{hr}$ urinary protein are inversely proportional to each other. The correlation coefficient between is -0.2167 . The graphical representation of this is shown in diagram. 4 .

Collection of $24 \mathrm{hr}$ urine samples is cumbersome and prone to errors, hence analyte measurement in random urine is often proposed with correction for variation in urine flow rate by expressing results as a ratio to creatinine concentration. It was not possible to formally assess completeness of collection of $24 \mathrm{hr}$ samples, particularly as there is little published data for CKD. Although samples were from a wellmotivated group of patients who regularly made $24 \mathrm{hr}$ collections.
Several studies have assessed the benefits of using random urine PCR as a surrogate for $24 \mathrm{hr}$ protein measurement, but relatively few of these have involved patients with kidney disease. Most studies have shown good correlations between PCR and $24 \mathrm{hr}$ protein loss $5,6,7,8$.

The NKF K/DOQI guidelines suggests that untimed spot urine samples should be used to detect and monitor proteinuria in children and adults, it prefers a first-morning sample, but accepts a random sample if a firstmorning specimen is not available. Few studies have previously assessed agreements rather than correlations between these tests and found wide limits. The limits of agreement were also wide, but similar across a wide range of protein excretion when data were log-transformed, the absolute difference between PCR and UP becomes very large as protein excretion increases. Urinary protein excretion is not constant and daily excretion varies by as much as $40 \%$ besides repeated 24-hour urine protein excretion varies by at least $15 \%$.

Rodby et al. repeated measurements on 33 patients at least three months apart and found discordant results were the PCR increased in some patients whereas the UP fell, and vice versa. Agrawal found a day to day variability in 24-hour urinary protein excretion of $10 \%$ and in protein-tocreatinine ratio of $2 \%$. This variability is a likely reason for the poor agreement between the two methods of assessing proteinuria $^{8}$.

Several investigators studied the relationship between the protein:creatinine ratio and 24-h protein excretion. Ginsberg et al. reported a correlation coefficient of 0.972; these authors also studied the variation of this relationship during the course of $24 \mathrm{~h}$ by studying the ratio and absolute amount of 
protein excreted in urine samples from 46 patients collected over timed periods throughout the day. They found that the relationship varied by as much as $30 \%$ but that during normal daylight activity — when most random samples are likely to be collected the variation was minimal. The greatest differences were seen during the times when the patients were most likely to be recumbent. These authors concluded on the basis of these data that the protein: creatinine ratio of a spot urine could be used as a reliable indicator of the $24-\mathrm{h}$ protein excretion. Several investigators have made similar observations and drawn similar conclusions, whereas others have stated a preference for the first sample collected after the first morning void.

Table.1 Causes of Chronic Kidney Disease

\begin{tabular}{|l|l|l|l|l|}
\hline & \multicolumn{1}{|c|}{$\mathrm{n}$} & $\begin{array}{c}\text { Diabetes } \\
\text { mellitus }\end{array}$ & Hypertension & Unknown \\
\hline All patients & 60 & 19 & 24 & 17 \\
\hline Males & 36 & 12 & 15 & 09 \\
\hline females & 24 & 07 & 09 & 08 \\
\hline
\end{tabular}

\begin{tabular}{|l|l|l|l|l|l|}
\hline & $\mathbf{n}$ & Age (years) & $\begin{array}{l}\text { Urine volume } \\
(\mathbf{L} / \mathbf{2 4 h})\end{array}$ & $\begin{array}{l}\text { Urine protein } \\
(\mathbf{m g} / \mathbf{2 4 h r})\end{array}$ & $\begin{array}{l}\text { Creatinine clearance } \\
(\mathbf{m l} / \mathbf{m i n})\end{array}$ \\
\hline All patients & 60 & $51.5 \pm 14.2175$ & $1.35 \pm 0.43333$ & $2089.5 \pm 580.192$ & $10.4602 \pm 0.53743$ \\
\hline Male & 36 & $52 \pm 12.20064$ & $1.34 \pm 0.3975$ & $2089.5 \pm 485.7697$ & $10.4775 \pm 0.52218$ \\
\hline Female & 24 & $49.5 \pm 12.6026$ & $1.41 \pm 0.4841$ & $2077 \pm 553.3312$ & $10.387 \pm 0.56858$ \\
\hline
\end{tabular}

Diagram.1 Protein to Creatinine Ratio Measured in Second Void Urine Compared with 24hr Urine Protein Loss. Correlation Coefficient were 0.50479

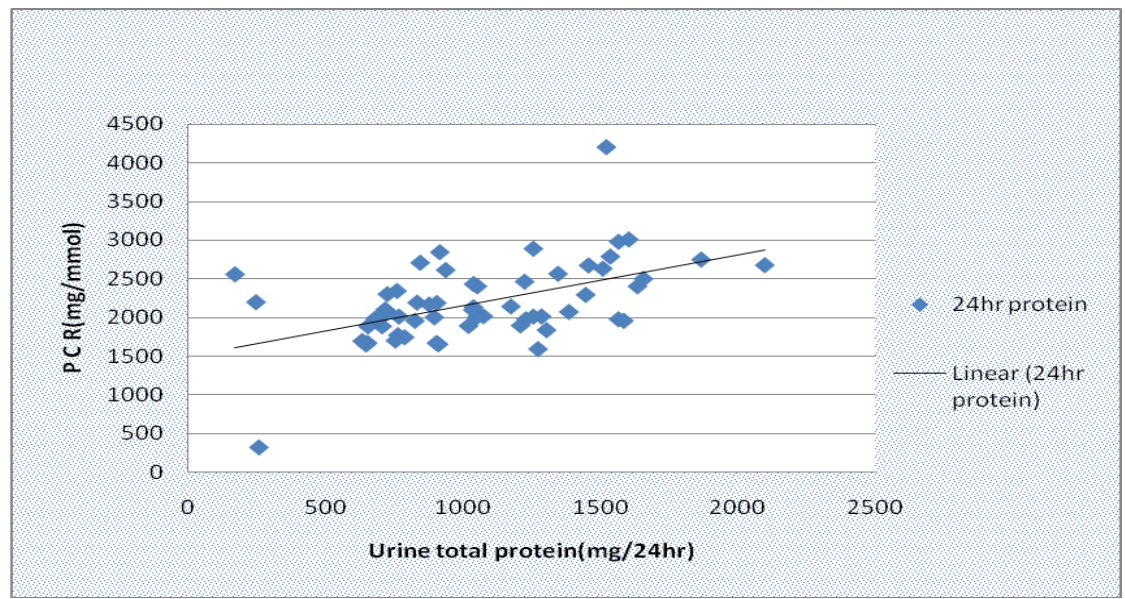


Int.J.Curr.Res.Aca.Rev.2016; 4(3): 170-177

Diagram.2 Protein to Creatinine Ratio Measured in Third Void Urine Compared with 24hr Urine Protein Loss. Correlation Coefficient were 0.5064

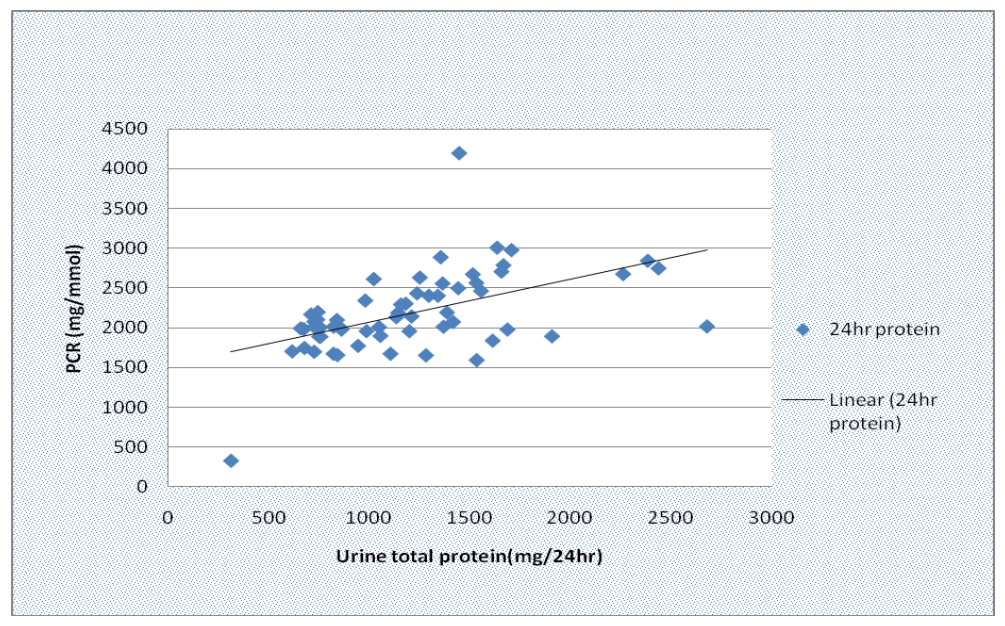

Diagram.3 Protein to Creatinine Ratio Measured in First Void Urine Compared with 24hr Urine Protein Loss. Correlation Coefficient were 0.69184

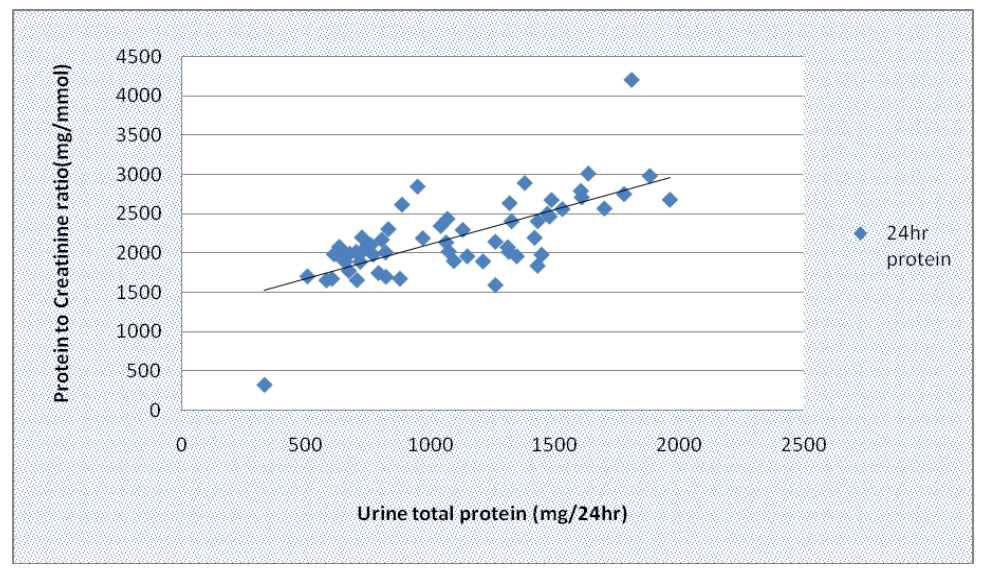

Diagram.4 Creatinine Clearance Compared with 24hr Urine Protein loss.

Correlation Coefficient were - 0.2167

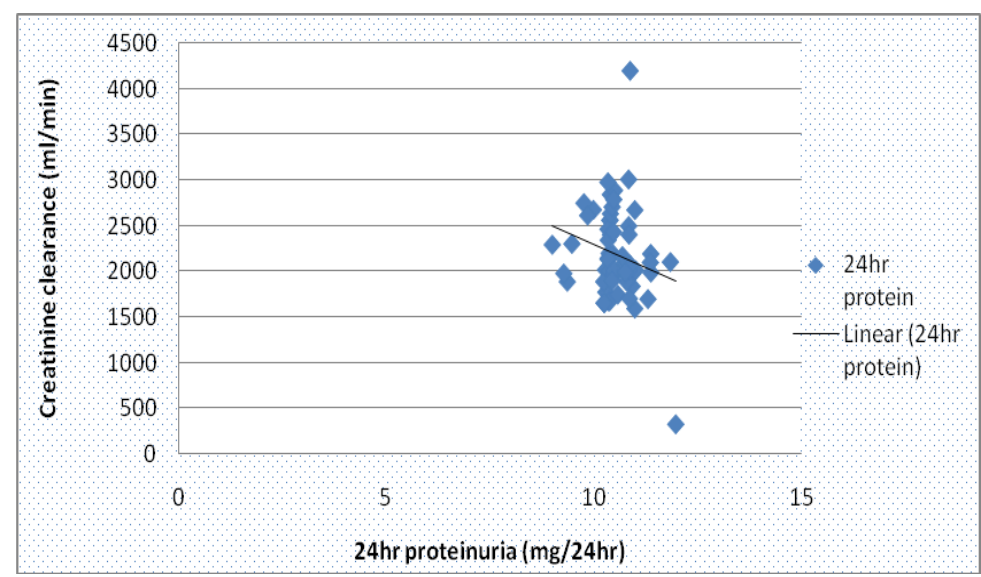


However, some authors have pointed out that regression analysis and the reporting of a correlation coefficient indicate the degree of linear association between the two variables but do not enable a reliable decision to be made to replace one with the other. Thus, the high degree of association between the protein: creatinine ratio and the 24-h protein excretion does not necessarily give reliable information on whether use of the ratio in a random sample will enable clinicians to reduce their dependence on the 24-h urine collection. ${ }^{9}$

For detection of proteinuria, the $\mathrm{P} / \mathrm{C}$ ratio presented a high level of accuracy. Two previous studies used the $\mathrm{P} / \mathrm{C}$ ratio cut-off values of 0.2 and 3.5 in patients with various nephropathies and stable renal function to establish the diagnosis of pathologic proteinuria $(\mathrm{P} 24 \geq 0.2 \mathrm{~g})$ and nephrotic range proteinuria $(\mathrm{P} 24 \geq 3.5 \mathrm{~g})$, respectively. In a study with pregnant women, Ramos et al. reported that the best cut-off to define normal protein excretion $(<0.3 \mathrm{~g})$ was a $\mathrm{P} / \mathrm{C}$ ratio.. Chitalia et al. described the $\mathrm{P} / \mathrm{C}$ values of 0.26 and 3.2 as the best cut-off points to establish critical levels of proteinuria. ${ }^{10}$

\section{Conclusion}

This study, have demonstrated good correlation between $24 \mathrm{hr}$ urine protein loss and PCR in second, third and early morning urines. But early morning urine PCR showed more correlation with $24 \mathrm{hr}$ urine protein loss.

\section{References}

1. Clinical chemistry (theory, analysis, correlation) by Lawrence A. Kaplan, Amadeo J. Pesce, Stanen C. Kajmiercjak. $4^{\text {th }}$ edition, page -486.
2. Harrison's Internal Medicine Vol.2, $17^{\text {th }}$ edition, page - 1762 .

3. Tietz text book of clinical chemistry and Molecular diagnosis $4^{\text {th }}$ edition page 822, 1241-45, 1687-89,1694.

4. Mark Guy, Joanna K Borzo mato Ronald G Newall, Philip A Kalra and cheistopher $\mathrm{P}$ Price. Protein and albumin to creatinine ratios in random urines accurately predict 24 hours protein and albumin loss in patients with kidney disease. Ann.Clin Biochem 2009; 46:468/476.

5. Anne-Marie Côté, Mark A Brown, Elaine Lam, Peter von Dadelszen, Tabassum Firoz, Robert M Liston and Laura A Magee. Diagnostic accuracy of urinary spot protein: creatinine ratio for proteinuria in hypertensive pregnant women: systematic review. BMJ. 2008 May 3; 336(7651): 1003-1006.

6. Wahbeh AM, Ewais MH, Elsharif ME. Comparison of 24hour urinary protein and protein-to-creatinine ratio in the assessment of proteinuria. Saudi $\mathbf{J}$ Kidney Dis Transpl.2009May;20 (3):443-7.

7. Morgenstern BZ, Butani L, Wollan P, Wilson DM, Larson TS. Validity of protein-osmolality versus proteincreatinine ratios in the estimation of quantitative proteinuria from random samples of urine in children. Am J Kidney Dis. 2003 Apr;41(4):760-6.

8. Cathei Lane, Mark Brown, William Dunsmoir, John Kelly and Ge0rge Mangos. Can spot urine protein/creatinine ratio replace $24 \mathrm{~h}$ urine protein in usual clinical nephrology? Nephrology (Carlton) 2006Jun:11(3):245-9.

9. Christopher P. Price, Ronald G. Newall and James C. Boyd. Use of Protein:Creatinine Ratio Measurements on Random Urine Samples for Prediction of Significant Proteinuria: A 
Int.J.Curr.Res.Aca.Rev.2016; 4(3): 170-177

Systematic Review Clinical and protein-to-creatinine ratio in the Chemistry:2005: 51: 1577-1586.

10. Ayman $M$ Wahbeh, Mohammad $\mathrm{H}$ Ewais, Mahamed E Elsharif.

Comparison of 24-hour urinary protein assessment of proteinuria. Saudi J Kidney Dis Transpl Year : 2009: 20(3): 443-447.

\section{How to cite this article:}

Komala, P.T., 2016. Protein Creatinine Ratio (PCR) from Random Urine Samples in Patients with Chronic Kidney Disease. Int.J.Curr.Res.Aca.Rev. 4(3): 170-177. doi: http://dx.doi.org/10.20546/ijcrar.2016.403.018 